\title{
Before Irenaeus: The Making of Grundtvig the Medievalist
}

\author{
By S. A. J. Bradley
}

Grundtvig's reading in Anglo-Saxon literature from 1815 onwards, long before his watershed meeting with Irenaeus, introduced him to a body of religious poetry characterised by its early medieval, patristic, oldkirkelige ideas and images. That these immediately appealed to him and perhaps confirmed views (for example on the interpretation of history) already forming in his mind, is evident from the interpretation he put upon Beowulf. His engagement with the four long scripture-based poems in the so-called Junius manuscript, attributed to the 7th-c. poet Cædmon, and with the Exeter Book of Anglo-Saxon religious poetry, continued his potential exposure to the oldkirkelige heritage, including the association of vernacular poems with the liturgical cycle of the Church's year. But not to be overlooked is the fact that the Thesaurus (1703-05; the work of George Hickes and Humphrey Wanley) through which Grundtvig gained much of his basic knowledge of this poetry, reflects Hickes's own commitment, as a non-juror priest and bishop in the English Church, to the catholic legacy of the pre-Reformation English Church. The record of Grundtvig's development over these earlier years needs to take account of what he found in Hickes-Wanley and in the literature to which they pointed him.

From 1815 onwards, Grundtvig became increasingly familiar with the literary legacy of the Anglo-Saxon culture. His encounter with the Anglo-Saxons culminated, according to conventional biography, in the three visits to England of 1829-31, from which he returned interested in contemporary issues of civil and religious liberty rather than in the ancient literature and culture he went there to research. However, such a view of Grundtvig's intellectual and spiritual growth from 1815 onwards, though it perhaps served its good purpose in its day, grows steadily less useful, as evidence is brought forth that his encounter with Anglo-Saxon culture was considerably more consequential than for one reason and another - modern Grundtvig scholarship has yet sufficiently acknowledged. ${ }^{1}$

It therefore seems worth looking again at some aspects of the English literary culture which Grundtvig explored from 1815 onwards. To some extent this entails going over old ground, already published ${ }^{2}$ but opportunity is taken here to look at his excursion from a somewhat different angle, to consolidate one particular area of argument for regarding the Anglo-Saxon encounter as very significantly formative 
in Grundtvig's development in the years between his first discovery of Anglo-Saxon literature and his discovery of the oldkirkelige, patristic theology of Irenaeus. Evidence is presented here of the way in which Grundtvig was brought into an extended experiencing, from as early as 1815, of the oldkirkelige in the European Christian tradition, the catholic and patristic inheritance from the early medieval church - in the context of his introduction at that date to Anglo-Saxon literature and culture. This exposure came about not solely through his primary encounter with the documents themselves, but also, importantly, through the editorial stance of those books of Anglo-Saxon scholarship which were available to Grundtvig in the Royal Library in Copenhagen when he began reading in Anglo-Saxon documents from 1815 onwards.

The extensive encounter with the early medieval and the oldkirkelige which ensued, I shall suggest, occurred within a context which predisposed Grundtvig to overcome any fastidiousness he might at that time of his life have felt over listening to the devotional and didactic voices of the pre-reformation, the monastic, Church. It is the implication of my arguments that this encounter with a rich, literary and (crucially) ancient Northern expression of the oldkirkelige forms some sort of prelude, perhaps even a precondition, of Grundtvig's dramatically fruitful engagement with Irenaeus - and that due account ought therefore to be taken of it in any adequate of Grundtvig's inward growth over these years.

It began with Beowulf, the Anglo-Saxon poem of some 3200 lines (or 6400 if one counts it, as the early scholars did, in half-lines) on themes from Danish-Swedish legendary history - a poem which, as Grundtvig saw long before anyone else, symbolically embodies a philosophy of history which is distinctively Christian-consistent and (we might say, though Grundtvig himself does not use the terminology) characteristically early-medieval. In 1815 Thorkelin published his heroic but flawed edition (Thorkelin 1815), the editio princeps of the unique Anglo-Saxon manuscript copy, datable palaeographically to about the year 1000 . Grundtvig, who of course knew that the edition had been on its way for some years, was naturally one of the most eager to read this ancient northern heroic poem - more ancient, as English scholars had already indicated, than the heroic and mythological poetry of Iceland.

According to his own claim, within two weeks Grundtvig acquired enough knowledge of Old English - the Anglo-Saxon language - to be able to read the text published by Thorkelin. Within weeks, he was jubilantly exposing errors in Thorkelin's text and in his understanding 
of its meaning. ${ }^{3}$ One has to acknowledge with some awe that usually Grundtvig was correct in his proposed readings and emendations of the text he had never seen in the original. A number of them stand attributed to him in modern editions of the poem.

Grundtvig now set about incorporating the whole phenomenon of Beowulf into the schematised world that he was then inhabiting. I say 'the phenomenon' because he is interested in much more than the text alone, as though he were an objective literary historian. The picture of Northern antiquity he had been building in earlier work now needed to be rearranged, to accommodate a newly identified skjald, a poet possessed, as he says, of a profoundly poetic vision, a poet of deep moral seriousness and of a poetic articulacy, a skill in fortcelling which excelled the finest of the Icelandic poets (Grundtvig 1820, Indledning og Fortale, p. L). But this new skjald was, moreover, a Christian poet. Within the world of the poem's plot, God the Creator presides - as he still does (says the poet-narrator) in the world of the present moment, that is, in the present of the poem's audience. In a remarkably conceived passage, where King Hrothgar's skjald sings in Heorot, the new-built folcstede [people's place], a hymn about the world's Creation, the poet celebrates the Creator Lord's delight in creation and sees the manifestation of the Creator within his creation, in its orderliness, beauty, radiance, and teeming life - and, at its centre, under God's providential care, humankind, endowed with knowledge of God and with creative visions and skills and a will to emulate God's bright order within the human family and community. Here a theological issue lies close in the background of this Anglo-Danish legend-history: that humankind preserves, despite the Fall, the image of God in which it was created; and that the establishment of human communality when it is ideally conceived both reflects the orderliness and beauty of God's primary act of Creation and will be providentially overseen by God.

The poetry of this skjald was therefore to be prized not merely for the heroic legend-history it preserved of the peodcyningas, the ancient people's-kings of Denmark, nor for the scraps of Northern myth it preserved, but for the poet's plain commitment to a distinctive and well worked-out 'theory of history' - a Christian philosophy of history, and one which was essentially characteristic of the thinking of the early Church. It was a philosophy of history which took the Scriptural history of the Old Testament (for example, the history of creation, of the first crime of violence within the family of humankind when Cain murdered Abel, of the Flood and the drowning of the giant species of Genesis 6) as archetypally symbolic - not only as prefigurative of what was then fulfilled in the New Testament (so to 
speak), but as defining the primary models, good and evil, of events in post-Scriptural history (for example, in the legendary history of the early kings, the folk-leaders, the folk-protectors, of ancient Denmark and Sweden). Thus the moral and universal significance of the present action within the story being told is enlarged when the action is presented as a reflex of a primary Scriptural model. Within this view, all human history is consequentially linked to the present time and to the future, within the overall purposes of a providential creator- and redeemer-God.

Nothing, surely, could have suited better the budding universal historian that Grundtvig at this time was. ${ }^{4}$ The remarkable, almost providential, thing was that this newly-accessible Beowulf fitted, ready-made, into that preoccupation Grundtvig was working his way through - and which notably finds expression through his work on Nordens Mytologi (1808) and through his periodical Danne-Virke (1816-19). I mean his preoccupation with history perceived as displaying an intelligible pattern from the beginning to the envisaged end, the record of the struggle between Truth and the Lie, the struggle he called Ordets Kamp til Seier [The struggle of the Word to victory]. ${ }^{5}$

Thus when, in another context, Grundtvig associates Rome with Grendel (the monster whose arm was torn off by Beowulf and who crawled away to die miserably in his lair) and associates Luther with Beowulf, he is not merely using literary allusion to coin a colourful metaphor of struggle; he is - in a remarkably medieval, even oldkirkelige way of thinking - locating this latter-day struggle of Luther and Rome within a lineage of ongoing struggles between Truth and the Lie, attested within ancient Northern legend (Beowulf) as it was within modern Northern history, and thus perceived within an ultimately Scripturally-defined history - that is itself a tissue of prefigurations and fulfilments, of events and their afterlives, each accruing meaning and signification from the other. ${ }^{6}$

Beowulf, then, was a discovery congenial to Grundtvig, the utterance of a poet whose working principles he was preconditioned to recognise and predisposed to embrace. But, as an experience, it was also formative. Beowulf is, for example, a poem which cannot be discussed without central reference to the concept of the folc, the people in community. When king Hrothgar forms the idea of building the great hall of Heorot only one motive is named by the poet: the king wishes to have a place where he may gather his folc together and share with all, with young and old, what God has given him. The hall is called by the poet the folcstede, the people's place. The ideal of human communality is endorsed in the poem by support from God. Acts of 
self-asserting and self-seeking individualism which threaten the community are represented as being monstrous - literally monstrous, and hellish, for this is the nature of the destroyer Grendel - "A spirit from Hell," Grundtvig calls him (Grundtvig 1817, 219-20), "Grendel, who builds in the wasteland, the devil's freehold, and preys, sick with envy, upon the folk" [en Helvedes Aand, Grændel som bygger i Ørken, Djævlenes Odel, og lurer avindsyg paa Folkets Glæde]. Grendel is associated by the poet with the devil. Unferth, the traitor within, is explicitly associated with the first man (in Scriptural history) to breach the integrity of human communality, of the family itself, namely Cain. Conversely, the hero is defined as heroic by his or her dedication to the orderly preservation of the people's peace and happiness under God. Beowulf himself ultimately dies in the final fight; the poet delivers a painful lesson in human mortality. But it was Grundtvig's distinction to see that the death was not in vain: the poet's message not one of ultimate pessimism, for Beowulf, in dying, saves the 'dying folkeliv' - as Grundtvig declares in his introduction to his Danish rendition of the poem in (Grundtvig 1820, Indledning og Fortale, p. L).

Without necessarily being aware of it, Grundtvig is perhaps already exposed here to distinctive ideas deriving from early medieval, Christian patristic thought - specifically that of St Augustine. Various scholars have found in Beowulf a distinctive perspective upon human community and upon worldly kingship and kingdoms which is broadly consistent with Augustine's City of God - a work certainly well known to the Anglo-Saxon world from early times. Beowulf, it may be understood from all this, is far from being a purely secular, purely narrative-heroic poem; nor, emphatically, did Grundtvig register his experience of it in such narrow and sterile terms. One way and another, Beowulf discovered to Grundtvig in 1815 a rich territory, a literature and a culture with impeccable title. It furnished material that responded to his particular demands of it, and which also fed him with authoritative, natively Northern, models of a Danish people, Christian and paternalistically monarchical, in a mutually benevolent relationship with their kings and queens - ideas which were not to come to full fruition in Grundtvig for some years, as Denmark moved from absolutism towards democracy - and along with all this also came an enhanced consciousness of the serviceability, perhaps the truth, of the early-medieval Christian, the oldkirkelige, rationale of human history.

Beowulf, though, is not the sum total of surviving Anglo-Saxon literature. It is only a small portion of it; and we know, both from the topics that begin to appear in his writings and from the protocols of the 
Royal Library in Copenhagen, that Grundtvig began reading his way into at least some of this literature from 1815 onwards. Though he quite liked to cultivate the impression that he was a lonely pioneer in largely uncharted territory, there were in fact already Anglo-Saxon texts, grammatical materials and scholarly studies in the Royal Library, mainly in books of English origin. They may well have been purchased by the Library upon the prompting of Thorkelin, who had already been working on Anglo-Saxon literature for some twenty years; or of Grundtvig's slightly younger contemporary in Copenhagen, the brilliant philologist Rasmus Rask (1787-1832). There may well have been accessible items going back to the time of the Danish national historians P. F. Suhm (1728-1798) and Jacob Langebek (1710-1775).

Grundtvig liked to think of himself as an historian at this period, and it is therefore very natural that he turned early to Bede, the eighthcentury author of the Latin Ecclesiastical History of the English People - the first history of the English people ever to be written, and a landmark document in the definition of an English sense of national identity. The Royal Library already owned the old edition by Abraham Whelock, who will shortly be mentioned again.

Bede, like the poet of Beowulf, trusted in a providential God and categorically and explicitly sought and found the pattern of this providence, directed towards the English people, in the history of the English Church and people. The mind which Bede brought to bear upon the testimony of history was a mind trained in the writings of Gregory the Great, Augustine of Hippo, Eusebius, Isidore of Seville, Ephraim of Syria - all great names in the annals of early Christendom. For Grundtvig this history also formed part of the history of Norden, the North, and it, like Beowulf, was ripe for his appropriation. The importance Grundtvig communicated to his followers concerning this text is reflected in the fact that (much later - in the critical year 1864) one of Grundtvig's immediate circle, Christian Kragballe, translated the Historia into Danish (Kragballe 1864); and he commended it in his Forord as a work which offered the Danish folk oplysning og opbyggelse, enlightenment and edification - not least for the testimony of true Christendom afforded by the ancient Church of the AngloSaxons against the corruptions of Lutheranism now prevalent (he declared) in the German Church, and because it was through the Anglo-Saxons that evangeliets kongevej, the highway of the gospel, was laid into the regions of the North (op. cit., 1-2).

In Bede, Grundtvig met the figure of Cædmon. Cædmon is presented by Bede as an historical figure living in the seventh century 
in the Anglo-Saxon monastery at Whitby on the cliff-tops of North Yorkshire's east coast. By a miraculous gift of the Holy Spirit, he became the first Christian poet in the English language, at some date before 680. In him, Grundtvig discovered a skjald of the highest authority - older than the Icelandic poets - historical, not legendarymythical - and Christian. At a critical period in his life, Grundtvig was able to use the figure of Cædmon to define an identity for himself. In a fairly specific way, in his poem Ragna-Roke (et dansk Amter) published in Danne-Virke III (1817), he represents himself as heir to this Northern poet who declares, in the poem, that he has received his harp from the hands of David the Psalmist himself. Grundtvig, in his concretisation of a mission for himself, worked out for himself, during those early years following the row over his dimis-prcediken, an identity as Grundtvig the poet-prophet, in the lineage of Cædmon and David, calling Christian folk to their duty to praise the Creator-God who restored life to the fallen world; and, I would add, he represented himself as heir to a seventh century monastic poet whose poetry was an exemplary exercise in patristic-based poetic exegesis of Scripture and redemption-history - the quintessence of the early-medieval in Anglo-Saxon Christian poetry.

The poems which in Grundtvig's time were commonly attributed to Cædmon are found in Oxford Bodleian Library MS Junius 11. They had been published in 1655 by François Du Jon, usually called Franciscus Junius (Junius 1655). The Royal Library owned a copy. Grundtvig became interested in them - in the longer term, very interested in them, to the extent of assembling materials for an edition, comprising transcriptions of the texts, linguistic annotations, and a prefatory poem which he composed in Anglo-Saxon. The very fat fascicule of draft materials (Fasc. 320) is to be found in the Grundtvig Arkiv in the Royal Library. What then did Grundtvig find, which so appealed to him, when he looked into the contents of this Anglo-Saxon manuscript? ${ }^{7}$

There are four lengthy poems, all based upon Scriptural narrative. The first relates to the book of Genesis, the second to the book of the Exodus, the third to the book of Daniel, and the fourth is based upon the New Testament account of Christ's forty days in the wilderness where he was confronted by, and where he overcame, the temptings of Satan. The poem Genesis emphasises in particular the Creation, Temptation and Fall of Man, the murder of Abel by Cain, and Noah's Flood. The poem Exodus is, naturally enough, mainly about the exodus, though it also contains a lengthy digression back to Noah's Flood. Daniel especially features the so-called 'Song of the Three Children' - that is, the canticle of praise to God uttered by the three 
Hebrew youths put into the fiery furnace for refusing to worship the gods of Babylon - plus the episodes of Nebuchadnezzar's insanity and Belshazzar's feast at which the hand appeared and wrote upon the wall in scarlet hieroglyphs the damnation of Belshazzar and the downfall of Babylon. The fourth poem, called Christ and Satan by modern editors, features the victory of Jesus over Satan in the desert, a moving narrative of Christ fetching Adam, Eve, the prophets and the patriarchs out of Hell (the Harrowing of Hell), and a lengthy and lurid account of Satan's wretched confinement to Hell.

These poems, however, are not primarily simple versifications of the biblical narratives. All of them individually constitute a form of exegesis the Scriptural texts. And together they comprise a perspective of redemption history, looking back to the Creation and Fall of Man, and looking onwards to the Last Judgment. It is a history in which events of the Old Testament prefigure a fulfilment in the New, and have an afterlife in the present time of the audience of the poem. Noah's ark, for example, prefigures the Church, and the pillar of light and fire which leads Moses out of Egypt prefigures the Cross. Noah's Flood and the Crossing of the Red Sea are clear prefigurations of the Church's sacrament of baptism. The poet provocatively calls the Hebrews, who walk across the dry bed of the Red Sea, 'seafarers'. The Egyptians he calls 'land-dwellers'. And thus he links them, and his narrative and polemic, to the universal motif of the pilgrim-seafarer and the worldly city-dweller - the citizen of the City of God seeking towards the heavenly homeland, land of the living, and the citizen of the civitas of this world, doomed by his arrogant and blind materialism to perish with the world. Unignorably, Augustinian and oldkirkelige categories are in play here.

There is much more of the same. In each poem appears the figure of a sodfoest man - a man who remains steadfast in the truth - Abel, Noah, Abraham, Moses, Daniel, the Three Children. God is referred to also as soðfoest - steadfast in his truth, in his covenant with his people - and, of course, in Christ and Satan appears the archetype of the sodfast man and Godhead, in Jesus, God made man. Thus, the human mirrors the divine; the image of God in man his creature is not utterly destroyed in the Fall. All this lay open to Grundtvig as he read the edition of Junius and, later, the modern edition of Benjamin Thorpe (Thorpe 1832).

I draw attention to just one further aspect of this corpus of AngloSaxon poetry studied by Grundtvig. It seems clear that these vernacular poems were composed to stand in some sort of relationship to the liturgy of Holy Week, and particularly to that selection of 
Scripture read, and the narrative of God's redemptive purpose reviewed, on Holy Saturday and in the Vigil of Easter, in the oldkirkelige tradition of the Anglo-Saxon Church. This function would well justify the organisation of these poems into a richly thematic account of redemption history, and would in particular justify the major featuring of Christ's Descent into Hell as part of the narrative of the final poem (Christ and Satan). It is striking to observe how this topic and article of faith (as embodied in the Creeds) - Christ's descent into Hell between crucifixion and resurrection - was particularly nurtured by Grundtvig and his followers, in theological discourse, poetic formulation and art. The Anglo-Saxon poetry of the Descent itself has been studied and translated by successive Grundtvigians and Grundtvig scholars, right up to Bent Noack only a few years ago (Noack, 1983).

In their scope, then, in their content, in their approach to scriptural exegesis, and in their role as some sort of devotional supplement to and exegesis of liturgy (akin in some respects to lections or to sermons), the poems of the 'Cædmon' codex are thoroughly patristic: they present their reader and audience with patristics mediated in poetry and in the Northern vernacular tongue of the Anglo-Saxons. Indeed, there is some justification, taking into account the whole corpus of Anglo-Saxon poetry together with its hinterland of sermoncycles, liturgical books, florilegia, translations from the Latin and Greek Fathers, and even religious art (which is no less didactic), to speak of 'insular patristics' distinctive of the early medieval period in the British Isles. ${ }^{8}$ Grundtvig himself comes close to putting the idea into words, in the introduction to his edition of the Anglo-Saxon poem The Phoenix (1840). There he speaks ironically of the learned folk who rationalise the Phoenix story into a fabulised account of the orbital cycle of the planets. They really seem to believe, he says, that the eternal truths of the Almanac are both far more important and more poetic than the whole of human life with all its changes, its entries and its exits, longings and hopes. They hardly know therefore how they are to excuse the Church Fathers who, as they needs must, saw in the Phoenix-Myth a beautiful prefiguration both of the Lord's resurrection and of ours; "but we, on the other hand, we shall take satisfaction in the fact that this interpretation is to be found yet more feelingly and more boldly set forth by the Anglo-Saxon poet than by any of the Church Fathers" [men vi vil derimod glæde os over, at denne Forklaring findes endnu langt varmere og dristigere udfört hos den Angel-Sachsiske Skjald end hos Nogen af Kirke-Fædrene] (Grundtvig 1840, 18-19). 
Characteristically, Grundtvig went on to make his own latter-day addition to the long tradition of exegesis of the Phoenix myth in Christian terms, as Professor Jens Holger Schjørring among others has shown (Schjørring 1993).

Besides the Beowulf codex and the codex containing the poems attributed to Cædmon, there was a third codex of Anglo-Saxon poetry known to Grundtvig. This was the so-called Exeter Book. During his visits to England, which included a journey down to Exeter to find the manuscript in the cathedral library there, Grundtvig transcribed the whole poetic contents of this codex, and long nursed the hope of producing an edition of it. He encouraged and assisted his sons' tutor, the young philologist Ludvig Müller, to publish an edition of the opening text, sometimes called Christ I or The Messiah - a gathering of lyric poems based upon the liturgical antiphons for the season of Advent (Müller 1835). These lyrics, which are in effect intense devotional exercises in preparation for receiving the new-born Christ into the heart purged by compunction, are a veritable treasure-house of the oldkirkelige, both in their liturgical context and in their rich, and exquisitely poetical, use of patristic concepts and images. A number of the other poems in the Exeter Book in fact relate, as do the poems of the 'Cædmon' manuscript, to the liturgical year of the Anglo-Saxon Church. They include a remarkable poem, The Descent into Hell, associated with Holy Saturday, which reflects the extensive preoccupation of the Anglo-Saxon Church - in verse and in prose, and in pictures as well as in words - with the popular early-medieval topos of the Harrowing of Hell, known to the Anglo-Saxons from the Latin and the English translation of the Gospel of Nicodemus. It was here in the Exeter Book that Grundtvig found The Phoenix which he published in 1840 at the accession of Christian VIII; and here that he perhaps found part of the inspiration for De Levendes Land as early as 1825 and of the Sidste Digt as late as 1872.

It strikes me as revealing, that when Grundtvig, in audience with the King in 1828, was selling His Majesty the idea of a trip or two to England to study the Anglo-Saxon manuscripts, he made much of the Danish-historical content which might be derived from these untapped resources; and thus he got his travel-grant. But what did he make a bee-line for when he got to England? The Exeter Book. To his amusement, he caused much consternation at the British Museum by requesting to see it. They barely knew where it was, and even less, he says, did they understand why anyone should trek over from Denmark to pore over it. He took the stage-coach down to Exeter, armed with a letter solicited from the Archbishop of Canterbury: he was determined 
to see the Exeter Book. He knew from Hickes and Conybeare what was in it. It was a bookful of religious poetry reflecting the character of the Anglo-Saxon Church; and he wanted to be the one who edited it for the public.

These three codices of Anglo-Saxon poetry, then, were sufficient to introduce Grundtvig to a fairly comprehensive early medieval Christian world-view - of the eternal shaping, providing, saving and judging God, Father, Son and Holy Spirit, creation, macrocosm and microcosm, the finiteness of time, times and seasons, history, language, revelations and riddles, metaphor and symbol, the sacraments given to nourish faith, the human faculties granted to enable men and women to recognise, approach and honour God, the instituted Church, the universal community of God's people - all in the poetic medium of the people's own Northern vernacular tongue. But besides these codices, and besides Bede's Latin Historia, and various manuscripts of English-language chronicles covering, from year to year, the centuries from the arrival of the Anglo-Saxons in Britain through to 1150; and besides collections of laws in Latin and English going back to the seventh century; Grundtvig could also see, from his first encounter with Hickes in 1815, that there survived a huge number of Anglo-Saxon sermons and homilies including two complete cycles to cover the whole Church year: "I have felt a high degree of interest in looking into this mirror of Anglo-Saxon divinity" he later wrote, "[...] because Anglo-Saxon preachers were the great instructors of the new Christian world" (Grundtvig 1830, 13). There also survived translations of the Bible and apocryphal books into English; translations of the writings of the Fathers of the Church, Eastern as well as Western; and of course the many liturgical books missals, sacramentaries, benedictionals, hymnals - giving between them a comprehensive first-hand account of the daily life and the yearly round of the Anglo-Saxon Church in its progress through the finiteness of time.

In order, however, to get a truer measure of the oldkirkelige character of what Grundtvig found himself exploring from 1815 onwards, we must take into account not only the texts themselves, but also the stance of the editors through whose eyes he received his first impressions of this corpus of ancient Northern Christian material. We know that he could have been reading (limited) material from the Exeter Book as early as 1815 , as soon as he started work on this (to him) newly-revealed language and literature. In 1826 was published a book entitled Illustrations of Anglo-Saxon Poetry, by John Josias Conybeare, Professor of Poetry in the University of Oxford. The Royal Library in Copenhagen immediately acquired a copy. But Conybeare 
had already published the bulk of his materials - including, for example, an account of the poem The Phoenix - in a series of articles (communications to the Society of Antiquaries) in the journal Archaeologia as early as 1813 . I now know that the Royal Library also acquired a copy of these articles, and there is every probability that they were already in the Library by the time Grundtvig turned his attention to Anglo-Saxon in $1815^{10}$

His chief source of information on the scope and content of the Anglo-Saxon literary corpus in 1815 was, however, Hickes's Thesaurus. This for Grundtvig, as for Anglo-Saxon scholars over several generations to come, was the great primary source-book, the one he called to mind at the very end of his life. A few days before he died, he asked Frederik Hammerich to read to him part of a newly edited Anglo-Saxon poetic meditation upon a ruined city (the poem we therefore call The Ruin), recently sent to him from England. Yes, said Grundtvig, after he had listened to Hammerich's reading: he knew the poem well, from Hickes's Thesaurus. As a matter of fact, he had read this poem for himself in the Anglo-Saxon manuscript itself, in the Exeter Book whence he transcribed it - but what he recalled was reading it in Hickes (Hammerich 1872; Johansen \& Høirup 1948, pp. 262-63). It therefore seems worth stopping to think about Hickes, and to reflect upon the values he pursued through his scholarly work, through the colleagues with whom he chose to work, through the texts he chose to focus upon, through the editors whose already published work he chose to incorporate in his monumental Thesaurus.

George Hickes (1642-1715) was a scholar, a clergyman in the Church of England, at one time chaplain to King James II, dean of Worcester, later titular bishop of Thetford, but importantly he was also a non-juror - one of those clergy who refused to swear allegiance to William and Mary in 1689, holding themselves still bound by the oath they had taken to the deposed king, James II. Of his great work, known as the Thesaurus (Hickes 1703-05), the Dictionary of National Biography (vol. IX, p. 803) justly says: "It is a stupendous monument of learning and industry, and that it should be the product of anxious years of suffering and perpetual turmoil affords wonderful testimony to the author's mental power and energy." The two majestic volumes, which were already in the Royal Library when Grundtvig began work on Anglo-Saxon in 1815, afford testimony to something else of significance to this present discussion: the author's sober but absolutely unyielding devotion to the oldkirkelige in the tradition of the English Church. 
The Thesaurus was in many respects a work well calculated to engage Grundtvig's interest and assent. Hickes dedicates his work to Prince Georg of Denmark. It has a magnificent dedication page, ornamented with the royal coat-of-arms and symbols of military might on land and at sea, which rehearses all Georg's titles: Hereditary Prince of Denmark, Norway, the Vandals and Goths, Duke of Slesvig, Holsten, Stormarn, Ditmarsken and so on. In the (Latin) dedication itself Hickes floridly hails the kings of Denmark as descendants of Odin, Lord of the Aesir, and of Skjold whence they have their name of Skjoldings. He recalls the legend of the brothers Dan and Angul, founding parents of, respectively, the Danish and the English peoples. He reminds the Prince that the Angles migrated to Britain from the regions of Slesvig and Holsten. Amid much else, he holds up Cnut the Great - Knud den Store - "Skioldingorum tunc Gloria" - at that time the glory of the Skjoldings. Fulsomely he declares: "A mightier emperor, a better king, or a wiser legislator the northern world has at no time seen" (Hickes 1703-05, Vol. I, Dedicatio, unnumbered p. 5), and he continues: "He, having acceded to governance by an agreed covenant, enlarged the empire of the Angles, amplified the glory of the name 'English' and established excellent laws pertaining to the ecclesiastical as well as to the civil commonweal, which are still extant, in the Anglo-Saxon language." As for Prince Georg himself, Hickes even more fulsomely praises his virtues, which are: "Prudence, Constancy, Reverence for things sacred, and the assiduous worship of immortal God." He prays, in conclusion, that Georg may live long with increasing glory to his name, and "that when he shall have migrated from among mortal men, ascending to those immortal and divine souls of the righteous who have been made perfect, and to the company of most blessed angels and to the Author of the New Covenant, Jesus, you may enjoy the supreme blessedness of the heavenly Jerusalem which, in that part of his Edda called Völuspá, Sæmundus called Frode, that is, the Wise, many centuries ago described in Icelandic, that is, in Gothic, from out of your ancient poetic monuments" - and he quotes four pairs of half-lines from Völuspá in Icelandic, with a parallel translation into Latin (op. cit., Dedicatio, unnumbered p. 8-9).

We might be cynical and note that all this fulsomeness paid off well: Hickes got a gift of one hundred guineas from Prince Georg. But this would be to do an injustice to Hickes. For one thing, he was apparently a man of the most rigorous integrity, and, as a non-juror, stoically paid many a penalty as a consequence. But more importantly, his historical assessment of Cnut and in his words about reverencing that which was sacred and about excellent laws protecting the Church, 
are expressions of Hickes's deep concern for the catholicity of the English Church. Vivid in his own consciousness of the identity, title and authority of the English Church was its ancient ancestry stretching far back into the early medieval period of European Christendom. In his Thesaurus he is making accessible a great variety of the surviving documents of this ancient Christian past, set in the wider linguistic and literary cultural context of the North; and Lutheran Denmark, he is tacitly reminding Prince Georg, shares through the exemplary Cnut in this oldkirkelige inheritance. The antiquity which Hickes so desires should remain a living part of the present, also embraces the antiquity of Christendom and the Church in England and in Scandinavia.

The Thesaurus is in two volumes. The second volume is a catalogue (with copious extracts from the texts) by the antiquary Humfrey Wanley. ${ }^{11}$ Wanley is not only a thoroughly efficient cataloguer; he also comments upon points of particular historic interest in the manuscripts and is a curious reporter of such details as notes left by former users of the manuscripts. Thus, for example, he examines the so-called St Augustine Gospels from Canterbury, and concludes from the evidence that he sees no reason why he should not affirm (what modern scholarship has continued to accept) that this is indeed one of the manuscript books sent by Gregory the Great to Augustine of Canterbury around the year 600 , and thereby one of the most ancient and venerable documents of the English Church. In another place (Thesaurus vol. II, 172) - and we should try to imagine Grundtvig's response on first coming across this note - he reports the judgment which Abraham Whelock (1593-1653), Professor of Arabic, Cambridge University Librarian and first university lecturer in AngloSaxon, wrote on the front of a codex of medieval homilies and sermons he had examined: "In very many ways this manuscript codex greatly does honour to the faith of Protestants. I have read it and studied it." We have already noted that some of Whelock's work, notably his edition of Bede's Ecclesiastical History of the English People, was in the Royal Library in Copenhagen and known to Grundtvig. Here is Whelock (or Wanley through Whelock), assuring Grundtvig and any other reader that these pre-Reformation English sermons were by no means all at odds with the orthodoxies of Protestantism. We can safely assume Grundtvig was not going to accept anyone else's mere assertion on that issue - but still we may think it was a striking and encouraging proposition for him to come across as he explored his way through the Thesaurus.

Curiously, then, Hickes had sketched out a landscape, a topography harmoniously incorporating ancient vernacular Northern 
poetry, myth and legend, national histories, royal dynasties, Northern Christendom and the Church, the early middle ages and postReformation modernity, which the Grundtvig of 1815 must have found immediately congenial to inhabit, and of which he took steadily increasing occupation over the decades ahead.

I have elsewhere (see note 9) offered a case for believing that it was from Hickes's Thesaurus - from Wanley's summary reference to a small cluster of texts whose collocation in the Exeter Book delineates a conventional area of early medieval religious thought and imagery - that Grundtvig took at least part of the inspiration for his poem De Levendes Land. ${ }^{12}$ This portion of the Exeter Book, Wanley reports, "comprises eight sections and treats of the joys which God has prepared for those who have loved him and fulfilled his bidding; with a poetic narrative of these, which Guthlac saw in the spirit when he was carried up into the skies (namely, the visions of Guthlac the anchorite)." This visionary poem - which broadly conforms with the model of the saint's life that goes back to the early medieval Life of St Anthony - ends with an allusion to lifgendra londes wynne, the joy of the land of the living, to which those who are faithful to Christ and true men of the sacrament shall attain. Whereas the phrase, when it is used in the Bible, always (as far as I know) signifies this present mortal existence, here in Guthlac it alludes to the heavenly homeland as it does in Grundtvig's poem.

This reference is followed by the incipit of The Phoenix, with its evocative opening formula "I have heard that far hence lies the noblest of lands" [Hoebbe ic gefrugnen patte is feor heonan apelast londa], strikingly and tellingly cast in the "first person" voice, the voice of the visionary prophet-poet. Further extracts from this poem had been published as recently as 1813 by the Oxford professor John Conybeare in the journal Archaeologia which I have already mentioned as being in the holdings of the Royal Library. Grundtvig's poem De Levendes Land opens to with a similar visionary statement, likewise couched in the first person.

The initial description of the land in which the Phoenix dwells (on the earth, but sharing the characteristics of Eden before the Fall, and of the heavenly homeland) is poetically based upon a series of rhetorical formulations of the singularity of this land where trees are forever green and fruit-bearing, there is no bad weather, no grief, senility, disease, strife, poverty.

In this collocations of text-summaries, then, appear three components of Grundtvig's poem - the concept and the words 'the land of the living'(meaning not this material world but the heavenly), the opening formula 'I know of a land' leading to a description of a 
heavenly paradise, and the distinctive rhetorical description of this paradisal garden where leaves do not wither, people do not grow old, where there is no sickness, no grief, and so on.

The Index of Wanley's Catalogue (Thesaurus, vol II) will afford any reader a quick impression of Grundtvig's experience on first looking into Hickes's Thesaurus. Just by taking the double opening, unnumbered pages 4 and 5 of Wanley's Index VI, we meet, as Grundtvig met, Bede, Benedict, Gregory, Augustine, Jerome, Beowulf, Bishops, Boethius, Cædmon, calendars and canons of the Church, Canute, Communion, Constantine, Creation, the Creed, Christ and Christianity, Christian Kingship, the Church, Daniel the Prophet, the Danes, David king and psalmist, the Descent of Christ into Hell, the Seven Gifts of the Holy Spirit, Apostolic doctrine, the Doxology and various devotions. It is a veritable cornucopia of early medieval Christendom.

There is much more research waiting to be done here. For example, we can see from the Royal Library protocols that already in 1815 Grundtvig had gone as far afield from Beowulf as to be reading King Alfred's ninth-century Anglo-Saxon translation of Boethius's Consolation of Philosophy, that key text in early medieval western Christendom. It evidently interested him enough for him to be borrowing it again, according to the Royal Library protocols, in 1820 . Alfred's translation, apart from being an historically significant experiment in the development of a vernacular English prose (spliced with verse renditions - which Grundtvig thought quite inept - of Boethius's metrical resumés), incorporated the king's own occasional commentaries and explanations. These served in part to construe the late-classical Latin work in Christian-consistent and vernacular terms. Thus when the king uses the Anglo-Saxon term wierd for Boethius's fortuna he explains that it refers not to the heathen concept of fate or destiny but to Divine Providence. In this respect, Alfred's Boethius is a text which mediates semantically between the heathen-mythological and the Christian-orthodox - within the parameters of this early Northern culture and this early Northern mother-tongue. How much of this, if any, Grundtvig absorbed, and what bearing, if any, it may have had upon his evolving approach to northern mythology and its symbolically signalled philosophy, or upon his evolving philosophy of history, remains, as far as I am aware, still to be investigated.

The Thesaurus, then, with Conybeare (1813) as back-up, provided what was probably the most definitive model of Anglo-Saxondom encountered by Grundtvig. It was a model which would lead him very 
much further onwards into early medieval Christendom than did, or could, Beowulf alone.

Even allowing for a little strategic flattery of the English subscribers he primarily addressed, it was a remarkable testimony to the impact of this early medieval Christian culture upon Grundtvig when he wrote in his prospectus, Bibliotheca Anglo-Saxonica (1830): "There is, therefore, no fact more pregnant of events in the whole of modern history, than the mission of Austin [Augustine] to this country [England], where Christianity, learning, and, in a word, all that was once expressed by the term 'humanity', found not only a shelter but a nursing-school, and from whence, in the process of time, it was to spread round the Baltic and the Scackerak. With Theodore of Greece and Adrian of Africa, classical literature, in the full extent to which it was then cultivated, was introduced into England; and from the beginning of the eighth century to the end of the eleventh she appears - not even excluding a comparison with the Eastern Empire - to have been the most truly civilized country on the globe. It was here that a whole nation listened to the songs of Caedmon and of Alcuin in their mother tongue, while in France and Italy nothing was heard but a jargon of barbarous sounds. It was here that, in the eighth century, Beda and Alcuin shed a lustre, by their classical attainments, over the whole of Europe; and it was from hence that Charlemagne, the sovereign of the greater portion of the Western World, was compelled to seek for an instructor. Even in these facts there is something dazzling, something which arrests the attention, and demands the homage of our respect; but, what is far more memorable and important in its consequences, it was Anglo-Saxon missionaries who carried Christianity to Germany and the North of Europe - missionaries from a country which, having a literature of its own, in a language akin to that of Germany and Scandinavia, made that literature the example, and that school the pattern, of all the early literary attempts of those parts of the world. Even in Denmark, notwithstanding the Gospel was first preached there as early as the beginning of the ninth century, it is clear, that it was only when a close connexion with England took place under Canute, that Christianity began generally and publicly to exert those humanizing powers which it has shed wherever it has been duly planted; and equally clear it is, that the literature of Iceland, which principally flourished during the twelfth and thirteenth centuries, is a pupil of the Anglo-Saxon school" (Grundtvig 1830, 4-5).

Bishop H. L. Martensen, recalling his visits as a young man to Grundtvig's home in the late 1830s, wrote of Grundtvig: "In history, we would often return to the Middle Ages and we talked at various times about Ansgar and his dreams. Grundtvig had a particular 
predilection for the Middle Ages, and declared that still in our own days there were characters who basically belonged in the Middle Ages; and I sometimes took the impression that he regarded himself as a medieval character" [I Historien vendte vi ofte tilbage til Middelalderen, og vi talede flere Gange om Ansgar og hans Drømme. For Middelalderen havde Grundtvig en særegen Forkjærlighed og yttrede, at der endnu i vore Dage vare Naturer, som i Grunden hørte hjemme i Middelalderen; og jeg fik stundom det Indtryk, at han betragtede sig selv som en middelalderlig Natur] (Martensen 1883, 181). Certainly, from 1815 onwards Grundtvig was increasingly wellsteeped in a literature, held by him to have a preeminent authority by virtue of being Northern, ancient and Christian, which was in itself early-medieval, patristic and oldkirkelig in character, and which was presented to the world by scholars interested in renewing awareness of the oldkirkelige roots and early medieval heritage of the English Church.

To what has already been achieved in the study of Grundtvig the "medieval character" discerned by Martensen, whose disposition it was to sympathise with, to accommodate and write within the tradition of the oldkirkelige, needs to be annexed the record of his early-begun, long-sustained and often detailed involvement with the early medieval Christian heritage so extensively embodied in Anglo-Saxon religious culture and spirituality.

\section{Bibliography}

Bradley, S. A. J. (tr., ed.) (1982), Anglo-Saxon Poetry. An anthology of Old English poems in prose translation with introduction and headnotes, London, Melbourne, Toronto.

Bradley, S. A. J. (1989-90), 'Grundtvig, Anglo-Saxon Literature, and "Ordets Kamp til Seier"' in Grundtvig-Studier 1989-90, 216-245.

Bradley, S. A. J. (1993), “The First New-European Literature” N. F. S. Grundtvig's Reception of Anglo-Saxon Literature' in A. M. Allchin, D. Jasper, J. H. Schjørring and K. Stevenson (eds), Heritage and Prophecy. Grundtvig and the English-Speaking World, Aarhus and Norwich, 45-72.

Bradley, S. A. J. (1999), 'The Recovery of England's "skrinlagt fortid" - a progress report' in Grundtvig-Studier 1999, 138-161.

Bradley, S. A. J. (2002), 'Grundtvig's Land of the Living and AngloSaxon scholarship in the Royal Library of Copenhagen' in Grundtvig-Studier 2002, 157-183. 
Conybeare, J. J. (1813), Archaeologia, or, Miscellaneous Tracts relating to Antiquity, London. Six papers on Anglo-Saxon poetry read to Society of Antiquaries, London.

Conybeare, J. J. (1826), Illustrations of Anglo-Saxon Poetry, Oxford.

Grundtvig, N. F. S. (1817), Danne-Virke, et Tidsskrift, vol. II-III, Copenhagen.

Grundtvig, N. F. S. (1820), Bjovulfs Drape. Et Gothisk Helte-Digt fra forrige Aar-Tusinde af Angel-Saxiske paa Danske Riim, Copenhagen.

Grundtvig, N. F. S. (1830), Bibliotheca Anglo-Saxonica. Prospectus, and Proposals of a Subscription, for the Publication of the most valuable Anglo-Saxon Manuscripts [etc], London.

Grundtvig, N. F. S. (1840), Phenix-Fuglen: Et Angelsachsisk Kvad, Copenhagen.

Grundtvig, N. F. S. (1861), Beowulfes Beorh eller Bjovulfs-Drapen, det old-angelske Heltedigt, paa Grund-Sproget, Copenhagen.

Grundtvig, N. F. S. (1871), Kirke-Spejl eller Udsigt over den christne Menigheds Levnetsløb, Copenhagen. In Johansen and Høirup 1948, 86-112.

Hammerich, Frederik (1872), 'Min sidste Samtale med Grundtvig' in Dansk Kirketidende, Copenhagen, cols. 675-76.

Hickes, George (1703-05), Thesaurus (vol. I, Linguarum Vett. Septentrionalium Thesaurus Grammatico-Criticus et Archoologus; vol. II, Librorum Veterum Septentrionalium, qui in Anglice Bibliothecis extant [...] Catalogus Historico-Criticus [etc.]), Oxford.

Johansen, Steen and Høirup, Henning (eds) (1948), Grundtvigs Erindringer og Erindringer om Grundtvig, Copenhagen.

Junius, Franciscus (ed.) (1655), Caedmonis monachi paraphrasis poetica Genesios [etc], Amsterdam.

Kragballe, Christian (tr.) (1864), Angler Folkets Kirkehistorie af Beda den Arvardige, Copenhagen.

Lundgreen-Nielsen, Flemming (1999), 'Grundtvig, angelsakserne og Sidste Digt' in Grundtvig-Studier 1999, 208-225.

Martensen, H. L. (1883), Af mit Levnet, II, excerpted in Johansen and Høirup 1948, 179-84.

Müller, L. C. (1835), Collectanea Anglo-Saxonica, Copenhagen.

Noack, Bent (tr.). (1983), Helvedstorm og Himmelfart, Copenhagen.

Schjørring, Jens Holger (1993), 'Om Fugl Fønix motivet. Til belysning af forholdet mellem poesi og kirkelære' in Carsten Bach-Nielsen et al, (eds), Ordet, kirken og kultur. Afhandlinger om kristendomshistorie tilegnet Jakob Balling, Aarhus, $379 \mathrm{f}$. 
Thorkelin, Grímur Jónsson (ed.) (1815), Beowulf. De Danorum rebus gestis secul. III \& IV. Poëma danicum dialecto anglo-saxonica. Ex bibliotheca Cottoniana Musaei Britannici edidit versione lat. et indicibus auxit Grim. Johnson Thorkelin, Copenhagen.

Thorpe, Benjamin (1832), Cadmon's Metrical Paraphrase of the Holy Scripture, London.

Vind, Ole (1999), Grundtvigs historiefilosofi, Copenhagen.

Whelock, Abraham (1643), Historice ecclesiastica gentis Anglorum libri $V[\ldots]$ tribus procipue mss. Latinis, a mendis repurgati: ab augustissimo [...] rege Aluredo, sive Alfredo, examinati; ejusque paraphrasi Saxonica [...] explicati; tribus [...] mss. Saxonicis collati: una cum annotationibus, \& analectis e publicis veteris ecclesice Anglicance homiliis, aliisque mss. Saxonicis [...] quibus in calce operis Saxonicam chronologiam [...] contexuimus: opera hoec [...] Saxonica [...] depromta e bibliotheca publica Cantabrigiensi, Cambridge.

\section{Notes}

The paper is substantially the text of a public lecture given in the Centre for Grundtvig Studies, University of Aarhus, in Autumn 2003.

1 A major step forward in the evaluation of the impact of his Anglo-Saxon discoveries upon Grundtvig is the recent assessment of the significance he attached to Beowulf as a kind of missing link connecting Northern antiquity (and therefore modernity) to the universal-historically perceived course of history from Scriptural antiquity onwards, in Vind 1999.

2 A review of progress in this field, and further relevant references, may be found in Bradley 1999.

3 Thus, in the pages of Nyeste Skilderier af Kjøbenhavn of that year took place the first ever serious and informed debate upon the poem Beowulfwhich therefore ranks among the earliest monuments in the history of modern Anglo-Saxon scholarship. The various contributions to the debate are in Nyeste Skilderier af Kjøbenhavn, Tolvte Aargang (1815), nos. 60, $63,64,65,66,67,68,70,71,72,75$ and 85 .

4 Grundtvig was already author of the Larebog $i$ Verdenshistorien (1808) and the Kort Begreb af Verdens Krønike betragtet i Sammenhoeng (1814), with their developed idea of the providential nature of history. In 1861 in the introduction to his edition of Beowulf he wrote: "Hvad der [...] giver Bjovulfs-Drapen verdenshistorisk og almen-videnskabelig Betydning og Vigtighed er dens levende Sammenhæng med de gamle Anglers verdenshistoriske Liv og Virksomhed i det Hele, der vel endnu kun er maadelig oplyst og mindre skattet, allermindst i Engeland selv, men er derfor dog lige store og for Aandens Øine umiskiendelige" [That which gives Beowulf universal-historical and universal scholarly significance and 
importance is its vivid connection with the ancient Angles' universalhistorical life and activities as a whole, which are still only passably illumined and less esteemed, and least of all (esteemed) in England itself, but which despite that are still just as great and unmistakable to the eye of the spirit] (Grundtvig 1861, xxiv). The place of the Anglo-Saxons in the universal history of Christendom had recently been defined by Grundtvig in his Christenhedens Syvstjerne [The seven stars (Pleiades) of Christendom] (1860).

5 References to Danne-Virke and some discussion of Grundtvig's treatment of Beowulf may be found in Bradley 1989-90.

6 Ragna-Roke. Et dansk Emter in Danne-Virke III (Grundtvig, 1817, 327).

7 A short account of this codex, and of each of the other principal AngloSaxon poetic codices and of the individual poems, together with English translations, is available in Bradley 1982.

8 The phrase was offered by Professor A. M. Allchin (personal communication), to take account of medieval religious poetry in Welsh as well as of the Anglo-Saxon poetry discussed here.

9 See Bradley 2002, 157-183 (De Levendes Land); Bradley 1993, 45-72, especially 65-70 (the Sidste Digt); and Lundgreen-Nielsen 1999, 208-225 (the Sidste Digt).

10 I am indebted to Kurt Johannes Dokkedahl for tracking down this item in the Royal Library Catalogue, on my behalf.

11 Humfrey Wanley (1672-1726) studied for a period (1695) at University College Oxford but never took a degree; as early as 1695 he was appointed assistant at the Bodleian Library in Oxford, and between 1699 and 1700 was engaged for Hickes in searching for Anglo-Saxon manuscripts through English libraries, this culminating in his catalogue forming vol. II of Hickes's Thesaurus, published 1705.

In pp. 279-282 of Wanley's Catalogus Historico-Criticus (Thesaurus, vol. II) are listed the 'Codices MSS. Anglo-Saxonici Ecclesiæ Exoniensis' [The Anglo-Saxon manuscript codices of the Church of Exeter]; on p. 280 occurs the descriptive heading referring to the codex of poetry known as The Exeter Book: "Deinde sequitur laudatum opus Poeticum Saxonicè Elegantioribus characteribus ante septingentos annos exaratum" [Hereafter follows the cited poetical work in Anglo-Saxon written in rather elegant characters seven hundred years ago]. 